\title{
Effect of Ozone Application on the Resin- dentin Microtensile Bond Strength
}

\author{
PCF Rodrigues • JB Souza $\bullet$ CJ Soares \\ LG Lopes • C Estrela
}

\begin{abstract}
Clinical Relevance
The use of ozone in the treatment of caries causes a significant reduction in the bond strength of restorative materials to dentin. However, its use with an antioxidizing agent was shown to increase bond strength values.
\end{abstract}

*Paula Cicília Faquim Rodrigues, Master, Federal University of Goiás, Department of Prevention and Oral Rehabilitation, Goiânia, Goiás, Brazil

João B. Souza, PhD, Federal University of Goiás, Prevention and Oral Rehabilitation, Faculdade de Odontologia da UFG, Primeira Avenida Esquina com Praça Universitária, Setor Universitário, Goiânia, Goiás, Brazil

Carlos J. Soares, DDS, MS, PhD, School of Dentistry, Federal University of Uberlândia, Operative Dentistry and Dental Materials, Uberlandia, Minas Gerais, Brazil

Lawrence G. Lopes, DMD, MDS, PhD, Federal University of Goiás, Prevention and Oral Rehabilitation, Faculdade de Odontologia da UFG, Primeira Avenida Esquina com Praça Universitária, Setor Universitário, Goiânia, Goiás

Carlos Estrela, DDS, MS, PhD, Federal University of Goiás, Department of Stomatologic Science, Praça Universitária Esquina com 1a Avenida, s/n, Setor Universitário, Goiânia, Brazil

*Corresponding author: Rua 9A 186 Ed.Mackenzie, Ap 301, Setor Oeste, Goiânia, Goiás 74110110 Brazil; e-mail: pcicilia@hotmail.com

DOI: $10.2341 / 10-062-\mathrm{L}$

\section{SUMMARY}

When ozone is used during caries treatment, bond strength can be compromised by the release of oxygen. The use of antioxidant agents neutralizes the free oxygen. The aim of this study was to evaluate the effects of ozone and sodium ascorbate on resin-dentin microtensile bond strength ( $\mu$ TBS). Forty human third molars were divided into four groups: Group 1, not treated with ozone; Group 2, ozone application followed by acid etching; Group 3, acid etching followed by ozone application; and Group 4, ozone and application of sodium ascorbate. Bonded beams $\left(1.0 \mathrm{~mm}^{2}\right)$ were tested under tension $\left(0.5 \mathrm{~mm} \mathrm{~min}{ }^{-1}\right)$. The $\mu$ TBS values were analyzed using one-way analysis of variance (ANOVA) and the Tukey test $(p=0.05)$. All beams that fractured were analyzed under stereomicroscopy $(40 \times)$. Group 1 had significantly higher $\mu$ TBS values than Group 2 or 3. The $\mu$ TBS values of Groups 1 and 4 were similar and higher than those of Group 2. The use of ozone in Group 2 resulted in lower values of $\mu$ TBS in all conditions evaluated. The 
predominant failure mode was adhesive. The application of ozone decreased the $\mu$ TBS of the dentin-composite resin interface. These values were reversed when compared with Groups 1 and 2 when sodium ascorbate was used.

\section{INTRODUCTION}

Ozone $\left(\mathrm{O}_{3}\right)$ is a powerful oxidant, which makes it an efficient antimicrobial agent. ${ }^{1-5}$ For this reason, it has been used for many years in medicine, and in more recent times in dentistry. ${ }^{6}$ Because of its bactericidal, fungicidal, and virucidal properties, ozone is widely used in several fields of dentistry, such as stomatology, endodontics, periodontics, surgery, and treatment of carious lesions. ${ }^{1,3,7}$ Its use in the treatment of carious lesions is due to its antimicrobial activity and its capacity to oxidize proteins within the lesions, thereby bringing about the diffusion of calcium and phosphate ions and leading to the remineralization of dental tissues. ${ }^{2,7,8}$ Holmes ${ }^{6}$ conducted a randomized clinical study and found that all leathery noncavitated primary root caries were arrested after treatment with ozone applications for 40 seconds. In a similar study, Baysan and $\mathrm{Lynch}^{2}$ found that most caries were arrested or reversed after the application of ozone for 10 and 20 seconds. The use of ozone may also result in the reversal of occlusal open carious lesions after curettage on the soft dentin until it reaches a leathery consistency. ${ }^{9}$

However, because of its high instability, ozone rapidly turns into oxygen, ${ }^{1,3}$ which may inhibit the polymerization of adhesive restorative material and thus reduce bond strength. ${ }^{10,11}$ This occurs because the reactivity of oxygen is much greater than that of the monomer. Therefore, if oxygen is available during polymerization, it will react with free radicals of the growing chains and affect polymerization. ${ }^{10,12}$

It has been suggested that an antioxidant agent should be applied to the surface exposed to oxygen free radicals to neutralize the effects of oxygenreleasing products and restore the bond strength of adhesive restorative material to dental substrate. ${ }^{13-16}$ Antioxidant agents, such as sodium ascorbate, composed of vitamin $\mathrm{C}$ and sodium, act as stabilizers of oxygen free radicals. Thus, their use allows restorations to be performed immediately after contact of the substrate with dental products that release oxygen as tooth whitening gel.

Adhesive procedures undertaken after ozone is used are a matter for concern, because this product can liberate oxygen radicals, and few studies have

\begin{tabular}{|ll|}
\hline Table 1: & Experimental Groups \\
\hline Group 1 & Acid etching, adhesive system, and resin composite \\
\hline Group 2 & $\begin{array}{l}\text { Ozone gas, acid etching, adhesive system, and } \\
\text { resin composite }\end{array}$ \\
\hline Group 3 & $\begin{array}{l}\text { Acid etching, ozone gas, adhesive system, and resin } \\
\text { composite }\end{array}$ \\
\hline Group 4 & $\begin{array}{l}\text { Ozone gas, sodium ascorbate, acid etching, } \\
\text { adhesive system, and resin composite }\end{array}$ \\
\hline
\end{tabular}

been found that evaluated significant variables. Thus, the current study evaluated the effects of ozone, alone or in conjunction with an antioxidant, on microtensile bond strength between dentin and resin composite. The hypothesis tested was that the application of ozone may affect the resin-dentin microtensile bond strength, and that this effect may be reversed by the addition of sodium ascorbate.

\section{METHODS AND MATERIALS}

Forty extracted human caries-free third molars $(n=40)$ were used. The teeth were collected after patient informed consent was obtained consonant with the 033/08 study approval issued by the Review Board of the Federal University of Goiás, Brazil. Residual soft tissue was removed from the tooth surface with a hand scaler. Teeth were stored in a $0.2 \%$ aqueous thymol solution for no longer than three months.

Occlusal enamel was removed by transversally cutting the specimens with a diamond saw at about $2.0 \mathrm{~mm}$ above the cementoenamel junction perpendicular to the long axis of the tooth. For this procedure, a diamond blade in an Isomet 1000 unit (Buehler Ltd, Lake Bluff, IL, USA) was used at low speed $(150 \mathrm{rpm})$ under constant irrigation with distilled water. A flat dentin surface was exposed after wet grinding of the occlusal enamel with 320grit $\mathrm{SiC}$ paper to complete enamel removal. Enamelfree exposed dentin surfaces were further polished using wet 600-grit silicon-carbide paper for 60 seconds to create a standardized smear layer. The teeth were stored in deionized water and then were randomly divided into four experimental groups consisting of 10 teeth for each condition tested $(\mathrm{n}=10)$, as shown in Table 1. The materials used in each study group and their manufacturers, composition, and batch numbers are presented in Table 2 . 
Table 2: Chemical Compositions and Batch Numbers of Materials Used in this Study

Material/manufacturer/batch no.

Composition

Total-etch $^{\mathrm{a}}$ (Dentsply Indústria e Comércio Ltda, Petrópolis, RJ, Brazil)/Batch 724970

Single Bond $2^{\mathrm{a}}$ (3M Dental Products, St Paul, MN, USA)/Batch 8RB
$37 \%$ phosphoric acid gel

Bis-GMA, HEMA, dimethacrylates, polyalquenoic and polyacrylic acid copolymer, photoinitiators, water, and ethanol

Bis-GMA, Bis-EMA, triethylene glycol dimethacrylate, camphorquinone, stabilizer and pigment. Color A3. Shade dentin

Sodium D-isoascorbate monohydrate, $10 \%$ in distilled water

Sodium ascorbate (Sigma Chemical Co, St Louis, MO, USA)/ Batch 03619DD

Abbreviations: Bis-EMA, ethoxylated bisphenol A glycol dimethacrylate; Bis-GMA, bisphenol-A diglycidylether methacrylate; HEMA, 2-hydroyxylethyl methacrylate. ${ }^{a}$ Materials were used according to manufacturers' directions.
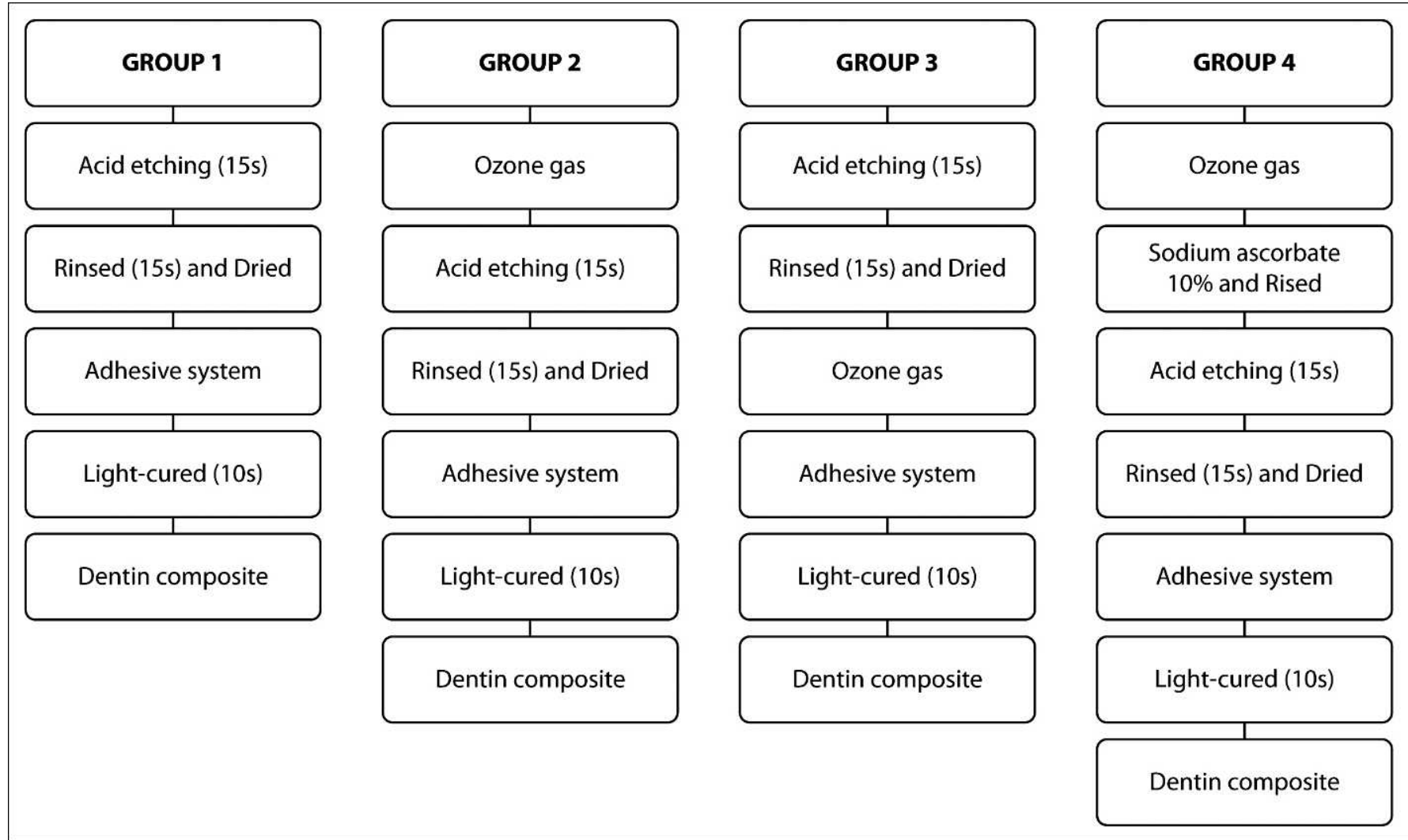

Figure 1. Experimental design.

The sequence of procedures performed in each group is described in the flow chart in Figure 1.

Ozone was applied to the flat dentin surface at a concentration of $5.0 \mathrm{~g} \mathrm{~L}^{-1}$ for 40 seconds $^{1,6,7}$ at $5 \mathrm{~g}$ $\mathrm{h}^{-1}$ of ozone flow rate. It was produced by electric discharge through an oxygen current (Generator
PXZ3507, Eaglesat Tecnologia em Sistemas Ltda, São José dos Campos, SP, Brazil). This part of the study was conducted in a dry environment (inside a modified autoclave to receive ozone only). The specimens were then irrigated with $10 \mathrm{~mL}$ of $10 \%$ sodium ascorbate for 10 minutes at a flow rate of 1 
$\mathrm{mL} \mathrm{min}^{-1}$, and afterward were washed with $10 \mathrm{~mL}$ of deionized water; excess water was removed with absorbent paper. ${ }^{13-16}$

Dentin was etched for 15 seconds with phosphoric acid, rinsed with deionized water for 15 seconds, and blotted dry with absorbent paper. Adhesive was applied with a microbrush to wet the surface, and then was brushed for 15 seconds. The same procedure was repeated for the second layer. The adhesive was light-cured for 10 seconds using a Lite Smart photoactivator (DeTrey Dentsply GmbH, Konstanz, Germany) at a light intensity of $950 \mathrm{~mW} / \mathrm{cm}^{2}$. The resin-composite build-up block was constructed to a height of $5 \mathrm{~mm}$ on bonded surfaces in $1 \mathrm{~mm}$ increments, which were light-activated for 10 seconds each using the same light unit and light intensity. All bonding procedures were carried out by a single operator.

After storage in deionized water at $37^{\circ} \mathrm{C}$ for 24 hours, the specimens were longitudinally sectioned in both " $\mathrm{x}$ " and " $\mathrm{y}$ " directions across the bonded interface with a diamond blade in an Isomet 1000 saw (Isomet 1000, Buehler Ltd) at $200 \mathrm{rpm}$ to obtain beams with cross-sectional areas of approximately 1 $\mathrm{mm}^{2}$ measured with a digital caliper (Absolute Digimatic, Mitutoyo, Tokyo, Japan).

All beams were mounted on testing apparatus with cyanoacrylate adhesive (Super Bonder Gel, Henkel Loctite Adesivos Ltda, Itapevi, SP, Brazil), applied over all faces ${ }^{17}$ and stressed to failure at 0.5 $\mathrm{mm} \min ^{-1}$ in a universal testing machine (Universal EMIC DL 2000, São José dos Pinhais, PR, Brazil). The fractured beams were carefully removed from the apparatus, and the cross-sectional area at the site of failure was measured to the nearest $0.01 \mathrm{~mm}$ with a digital caliper. Measurements were recorded for the calculation of bond strength. The $\mu$ TBS value of each beam was calculated as the force $(\mathrm{N})$ at failure divided by the bonded area $\left(\mathrm{mm}^{2}\right)$ and expressed in MPa.

Bond failure modes were evaluated using stereomicroscopy (Olympus SZPT 40, Tokyo, Japan) at 40× magnification and were classified as adhesive (failure at resin-dentin interface); cohesive in resin composite (failure of resin composite); cohesive in dentin (dentin failure in dentin); and mixed (mixed with cohesive failure of neighboring substrates).

The experimental unit was the tooth. The value of the bond strength of each beam was obtained through a microtensile test. Each group contained 10 teeth, and each tooth generated an average of 10 beams. Thus, the mean of the bond strength values

\begin{tabular}{|lcc|}
\hline Table 3: & $\begin{array}{l}\text { Mean } \mu \text { TBS (MPa) and Standard Deviation (SD) } \\
\text { Obtained in Tested Groups }\end{array}$ \\
\hline Group & $n$ & $\mu T B S$ \\
\hline Group 1 & 10 & $29.7(3.7)^{\mathrm{a}}$ \\
\hline Group 2 & 10 & $15.0(4.6)^{\mathrm{c}}$ \\
\hline Group 3 & 10 & $20.7(4.5)^{\mathrm{b}}$ \\
\hline Group 4 & 10 & $25.3(4.9)^{\mathrm{ab}}$ \\
\hline${ }^{*}$ Groups with different superscript letters are significantly different $(\mathrm{p}<0.05)$. \\
\hline
\end{tabular}

in each group represented the sum of the 10 experimental units.

Because only one factor was under study, one-way analysis of variance (ANOVA) was used. The Tukey test for multiple comparisons between means was used to complement ANOVA and to identify the values that differed significantly from each other. The level of confidence was established at $p=0.05$.

\section{RESULTS}

Only results for beams that did not debond before microtensile testing are presented. Results of oneway ANOVA revealed statistically significant differences between groups ( $p=0.001 ; F=19.603$ ). Means and standard deviations of microtensile bond strength values are shown in Table 3 and Figure 2.

Bond strengths between the resin composite and the dentin in Group $1(29.7 \pm 3.7)$ were significantly higher than in Groups 2 and $3(15.0 \pm 4.6$ and 20.7 $\pm 4.5 ; p=0.001)$. Groups 1 and 4 showed similar

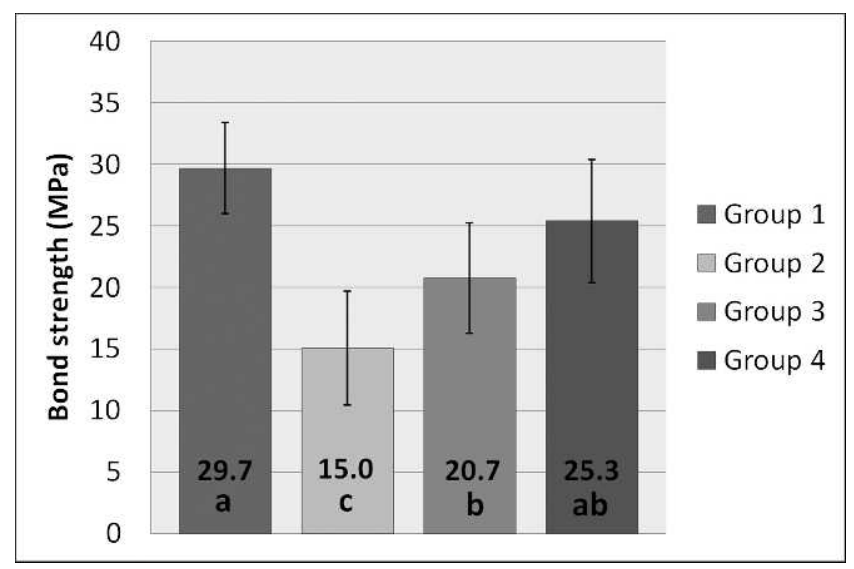

Figure 2. Mean $\mu$ TBS (MPa) and Standard Deviation (SD) obtained in the tested groups. 


\begin{tabular}{|lcccc|}
\hline Table 4: & $\begin{array}{l}\text { Percentage of Failure Modes of Specimens } \\
\text { Fractured in Tested Groups }\end{array}$ \\
\hline & \multicolumn{4}{c|}{ Failure Mode, \% } \\
\cline { 2 - 5 } & Adhesive & Mixed & $\begin{array}{c}\text { Cohesive in } \\
\text { Dentin }\end{array}$ & $\begin{array}{c}\text { Cohesive in } \\
\text { Composite }\end{array}$ \\
\hline Group 1 & 56.8 & 30.0 & 4.4 & 8.8 \\
\hline Group 2 & 71.0 & 27.6 & 0.7 & 0.7 \\
\hline Group 3 & 68.1 & 29.7 & 1.1 & 1.1 \\
\hline Group 4 & 68.9 & 29.9 & 1.2 & 0 \\
\hline Total & 66.9 & 28.9 & 1.7 & 2.5 \\
\hline
\end{tabular}

values, and no significant differences were noted between these two groups ( $p=0.158$ ). The mean value was higher in Group 4 than in Groups 2 and 3, but it was significantly higher when compared with Group $2(p=0.001)$.

The use of ozone before etching (Group 2) resulted in a bond strength value that was significantly lower than that found for Group 3, in which ozone was applied after etching ( $p=0.035)$.

Table 4 summarizes the percentage of failure modes of specimens fractured in the test groups. The predominant failure mode was adhesive. High rates of cohesive failure were noted in Group 1; this is normally associated with higher bond strength. Cohesive failures were not detected in Group 4.

\section{DISCUSSION}

Because of its antimicrobial action, ozone may bring about the inhibition or destruction of various oral microorganisms, such as Gram-positive and Gramnegative Candida albicans. ${ }^{1-3,5-7,18}$ Ozone would seem to be a promising therapy for the treatment of root and occlusal caries and noncavitated occlusal carious lesions. ${ }^{1,2,5-9}$ In the treatment of caries, pyruvic acid, which contributes substantially to the decreased $\mathrm{pH}$ values associated with active carious lesions, is oxidatively decarboxylated to acetate, carbon dioxide, and oxygen on reaction with ozone. ${ }^{19}$ Consequently, ozone is an unstable molecule that rapidly decomposes into oxygen. ${ }^{1,3}$ Oxygen can inhibit the polymerization of adhesive systems and consequently can reduce the bond strength between adhesive restorative materials and hard tissues. ${ }^{10,11}$
A typical example is the bond strength reduction observed after dental bleaching with hydrogen peroxide or carbamide peroxide caused by the presence of residual oxygen. ${ }^{11,20}$ The fact that this study showed a statistically significant reduction in $\mu$ TBS values after ozone application when compared with Group 1 (without ozone application) may be attributed to the presence of residual oxygen after the use of ozone. Contrary to what was observed by Schmidlin, Bindl, and Zimmermann, ${ }^{21}$ who evaluated the effects of ozone application on the dentin and enamel of bovine teeth in terms of shear bond strength, no reduction in adhesion was observed between the dental substrate and the resin composite. Similar findings were reported by $\mathrm{Al}$ Shamsi and others, ${ }^{22}$ who found no significant reduction in the shear bond strength of orthodontic brackets to enamel when ozone was applied for 10 seconds after conditioning and bonding, and immediately after bonding before the adhesive procedure was performed.

Lack of consonance between the results of this research and the above mentioned findings may be associated with the fact that other studies used the mechanical shear test to evaluate bond strength, whereas this study used a microtensile test. The shear test examines areas of greater union and is associated with a nonuniform distribution of stresses on the adhesive interface. ${ }^{23,24}$ To minimize the uneven distribution of forces during bond strength testing, the microtensile test ${ }^{24,25}$ utilizes very small areas of union $\left(05-1.0 \mathrm{~mm}^{2}\right)$, and as a result demonstrates fewer defects at the interface. ${ }^{25,26}$

In addition, differences in results may be associated with the type of dental substrate under analysis; this research evaluated the bond strength of dentin, whereas $\mathrm{Al}$ Shamsi and others ${ }^{22}$ used only enamel. Dentin, which contains a considerable volume of water and organic matter, is a wet tissue formed by dentinal tubules, and the presence of a smear layer makes bonding to the substrate more difficult when compared with enamel, which is composed mainly of hydroxyapatite that adheres to adhesive systems and promotes a stronger bond than that obtained with dentin. ${ }^{27}$ In addition, Schmidlin, Bindl, and Zimmermann ${ }^{21}$ used bovine teeth to test bond strength, whereas human teeth were used in this research. Moreover, the dose of ozone used in this study might account for the difference between the findings of this study and those of other investigators. ${ }^{21,22}$ This study used a higher concentration of ozone than was used in the other studies. ${ }^{21,22}$ 
Because the use of ozone is quite recent and not very widespread, and because few studies have been undertaken to evaluate bonding strength, the results obtained with use of a control group in this research were compared with those of other studies, which used approximate methods and materials. In the latter, the values of $\mu$ TBS were $29.7 \pm 4.3,{ }^{28} 29.2 \pm$ $8.5,{ }^{29}$ and $34.1 \pm 4.6,{ }^{30}$ which approximated values of the control group in this study.

The order of ozone application and acid etching was changed in two of the study groups (Groups 2 and 3) to evaluate a possible change in $\mu$ TBS. The protocol of phosphoric acid etching of dentin before ozone application (Group 3) was delineated to observe whether ozone gas would be inactivated by phosphoric acid in a normal application, as visualized in Group 2. Group 3 showed a statistically significant increase in the value of bond strength when compared with the group in which conditioning was performed after ozone application (Group 2). This result was contrary to what was expected, because in Group 3, ozone was applied immediately before the adhesive system was used. However, some chemical interaction might have occurred between ozone and phosphoric acid when the acid was used after the ozone. Ozone molecules found in the dentin substrate after application may affect the action of the phosphoric acid used to condition dentin, and may interfere with adhesion to the substrate. Etching exposes the collagen fibrils, which are interpenetrated by monomers (primers), and forms a hybrid layer, which is one of the most likely elements to adhere to dentin. ${ }^{31,32}$ Any interference with formation of the hybrid layer may affect the bonding strength of adhesive materials to dentin. Thus, the authors believe that Group 3 showed the direct and true effects of residual molecules of oxygen on bond strength, which were significantly different from those seen in the control group.

To neutralize the oxidative effects of ozone, $10 \%$ sodium ascorbate was applied for 10 minutes after ozone was used. Analysis of the results showed that sodium ascorbate reversed the bonding strength values of adhesive composites to human dentin. It is possible that sodium ascorbate could have a certain capacity to alter the oxidizing agents via a redox reaction on the treated substrate. ${ }^{16}$ Although no studies have been done to evaluate the use of ascorbate after ozone, these results were expected as part of the same principle and in consonance with studies that evaluated the effect of an antioxidant on the bond strength of an adhesive composite to enamel/dentin after dental bleaching or sodium hypochlorite use. ${ }^{13,14,16}$ Using an antioxidant for 10 minutes is not realistic. However, the length of time chosen for application was based on certain studies, ${ }^{14,33}$ which used this antioxidant agent. The study by Weston and others ${ }^{16}$ showed that 1 minute treatment with $10 \%$ sodium ascorbate was just as effective as 10 minutes of this treatment. Therefore, this may be a viable alternative for clinical use.

The fracture mode of beams submitted to bond testing should be consider when bond strength is measured. ${ }^{24}$ Stereomicroscopy and descriptive analysis in this study revealed the prevalence of adhesive fractures in all groups; this finding validates this study because the values recorded estimate, in general, actual bond strength on the adhesive interface. However, the control group, which obtained the highest value of $\mu$ TBS (MPa), presented a greater number of cohesive fractures in dentin than did the other groups.

Few studies have been carried out to investigate the application of ozone to hard tissues and bonding. In one study, ozone applied for 40 seconds did not change the physical characteristics of enamel, nor did it negatively affect microleakage or sealant penetration. ${ }^{18}$ In another study, application of ozone to dentin for 120 seconds did not compromise the mechanical properties of the Prime \& Bond NT, Excite, Silorane, or Syntac/Heliobond adhesive systems. ${ }^{34}$ Biter and others ${ }^{35}$ evaluated the effects of ozone on the push-out bond strength of fiber posts to root canal dentin. Their results showed that treatment with ozone might affect the retention of adhesively luted fiber posts, depending on the luting agent, that is, adhesion of the self-adhesive resin cement RelyX Unicem was significantly reduced after gaseous ozone was used, although an increase in bond strength was noted when Panavia 2.0 cement was used after the use of ozone.

Results of this study show that ozone application and its use with sodium ascorbate affect $\mu$ TBS values; this confirms the hypothesis of this study. Ozone application to dental substrates before adhesive restorations is seen to have implications. Additional studies should be conducted to broaden our knowledge of the action of ozone on the surface structure.

\section{CONCLUSIONS}

- Under the conditions tested and within the limitations of this in vitro study, ozone decreased microtensile bond strength between dentin and composite resin, but the use of an antioxidant after 
ozone application reversed the values of microtensile bond strength after ozone application.

(Accepted 27 October 2010)

\section{REFERENCES}

1. Baysan A, Lynch E, \& Grootveld M (2001) The use of ozone for the management of primary root carious lesions In: Albrektsson TO, Bratthall D, Glantz PJ, Lindhe JT (eds) Tissue Preservation and Caries Treatment Quintessence, Chicago 49-67.

2. Baysan A, \& Lynch E (2004) Effect of ozone on the oral microbiota and clinical severity of primary root caries American Journal of Dentistry 17(1) 56-60.

3. Stubinger S, Sander R, \& Filippi A (2006) The use of ozone in dentistry and maxillofacial surgery: A review Quintessence Internacional 37(5) 353-359.

4. Estrela C, Estrela CRA, Decurcio DA, Hollanda ACB, \& Silva JA (2007) Antimicrobial efficacy of ozonated water, gaseous ozone, sodium hypochlorite and chlorhexidine in infected human root canals International Endodontic Journal 40(2) 85-93.

5. Azarpazhooh A, \& Limeback H (2008) The application of ozone in dentistry: A systematic review of literature Journal of Dentistry 36(2) 104-116.

6. Holmes J (2003) Clinical reversal of root caries using ozone, double blind, randomised, controlled 18-month trial Gerodontology 20(2) 106-114.

7. Baysan A, Whiley RA, \& Lynch E (2000) Antimicrobial effect of a novel ozone-generating device on microorganisms associated with primary root carious lesion in vitro Caries Research 34(6) 498-501.

8. Baysan A, \& Lynch E (2007) Clinical reversal of root caries using ozone: 6-month results American Journal of Dentistry 20(4) 203-208.

9. Dahnhardt JE, Jaeggi T, \& Lussi A (2006) Treating open carious lesions in anxious children with ozone: A prospective controlled clinic study American Journal of Dentistry 19(5) 267-270.

10. Rueggeberg FA, \& Margeson DH (1990) The effect of oxygen inhibition on an unfilled/filled composite system Journal of Dentistry Research 69(10) 1652-1658.

11. Cavalli V, Gianinni M, \& Carvalho RM (2004) Effect of carbamide peroxide bleaching agents on tensile strength of human enamel Dental Materials 20(8) 733-739.

12. Suh BI (2004) Oxygen-inhibited layer in adhesion dentistry Journal of Esthetic and Restorative Dentistry 16(5) $316-323$.

13. Lai SC, Tay FR, Cheung GS, Mak YF, Carvalho RM, Wei SH, Toledano M, Osorio R, \& Pashley DH (2002) Reversal of compromised bonding in bleached enamel. Journal of Dental Research 81(7) 477-481.

14. Kaya AD, \& Turkun M (2003) Reversal of dentin bonding to bleached teeth Operative Dentistry 28(6) 825-829.

15. Vongphan N, Senawongse P, Somsiri W, \& Harnirattisai C (2005) Effects of sodium ascorbate on microtensile bond strength of total-etching adhesive system to $\mathrm{NaOCl}$ treated dentine Journal of Dentistry 33(8) 689-695.

16. Weston CH, Ito S, Wadgaonkar B, \& Pashley DH (2007) Effects of time and concentration of sodium ascorbate on reversal of $\mathrm{NaOCl}$-induced reduction in bond strengths Journal of Endodontics 33(7) 879-881.

17. Soares CJ, Soares PV, Santos-Filho PC, \& Armstrong SR (2008) Microtensile specimen attachment and shapefinite element analysis Journal of Dental Research 87(1) 89-93.

18. Celiberti P, Pazera P, \& Lussi A (2006) The impact of ozone treatment on enamel physical properties American Journal of Dentistry 19(1) 67-72.

19. Grootveld M, Silwood CJ, \& Lynch E (2006) High resolution 1HNMR investigations of the oxidative consumption of salivary biomolecules by ozone: relevance to the therapeutic applications of this agent in clinical dentistry Biofactors 27(1-4) 5-18.

20. Attin T, Hannig C, Wiegand A, \& Attin R (2004) Effect of bleaching on restorative materials and restorations-A systematic review Dental Materials 20(9) 852-861.

21. Schmidlin PR, Zimmermann J, \& Bindl A (2005) Effect of ozone on enamel and dentin bond strength The Journal of Adhesive Dentistry 7(1) 29-32.

22. Al Shamsi AH, Cunningham JL, Lamey PJ, \& Lynch E (2008) The effects of ozone gas application on shear bond strength of orthodontic brackets to enamel American Journal of Dentistry 21(1) 35-38.

23. Retief DH (1991) Standardizing laboratory adhesion tests American Journal of Dentistry 4(5) 231-236.

24. Pashley DH, Sano H, Ciuchi B, Yoshiyama M, \& Carvalho RM (1995) Adhesion testing of dentin bonding agents: A review Dental Materials 11(2) 117-125.

25. Pashley DH, Carvalho RM, Sano H, Nakajima M, Yoshiyama M, Shono Y, Fernandes CA, \& Tay F (1999) The microtensile bond test: A review Journal of Adhesive Dentistry 1(4) 299-309.

26. Sano H, Shono T, Sonoda H, Takatsu T, Ciucchi B, Carvalho R, \& Pashley DH (1994) Relationship between surface area for adhesion and tensile bond strengthEvaluation of a micro-tensile bond test Dental Materials 10(4) 236-240.

27. Pashley EL, Tao L, Matthews WG, \& Pashley DH (1993) Bond strengths to superficial, intermediate and deep dentin in vivo with four dentin bonding systems Dental Materials 9(1) 19-22.

28. de Silva AL, Lima DA, de Souza GM, dos Santos CT, \& Paulillo LA (2006) Influence of additional adhesive application on the microtensile bond strength of adhesive systems Operative Dentistry 31(5) 562-568.

29. de Goes MF, Giannini M, Di Hipólito V, Carrilho MR, Daronch M, \& Rueggeberg FA (2008) Microtensile bond strength of adhesive systems to dentin with or without application of an intermediate flowable resin layer Brazilian Dental Journal 19(1) 51-56.

30. Loguercio AD, Stanislawczuk R, Polli LG, Costa JA, Michel MD, \& Reis A (2009) Influence of chlorhexidine digluconate concentration and application time on resin- 
dentin bond strength durability European Journal of Oral Sciences 117(5) 587-596.

31. Nakabayashi N, Kojima K, \& Masuhara E (1982) The promotion of adhesion by the infiltration of monomers into tooth substrates Journal of Biomedical Materials Research 16(3) 265-273.

32. Nakabayashi N (1992) he hybrid layer: A resin-dentin composite Proceedings of the Finnish Dental Society 88(Supplement 1) 321-329.

33. Turkun M, \& Kaya AD (2004) Effect of $10 \%$ sodium ascorbate on the shear bond strength of composite resin to bleached bovine enamel Journal of Oral Rehabilitation 31(12) 1184-1191.

34. Magni E, Ferrari M, Hickel R, Huth KC, \& Ilie N (2008) Effect of ozone gas application on the mechanical properties of dental adhesives bonded to dentin. Dental Materials 24(10) 1428-1434.

35. Bitter K, Noetzel J, Volk C, Neumann K, \& Kielbassa AJ (2008) Bond strength of fiber posts after the application of erbium: Yttrium-aluminum-garnet laser treatment and gaseous ozone to the root canal Journal of Endodontics 34(3) 306-309. 